E3 Journal of Business Management and Economics Vol. 8(1). pp. 026-037 April, 2017

Available online http://www.e3journals.org

ISSN 2141-7482 @ E3 Journals 2017

DOI : http://dx.doi.org/10.18685/EJBME(8)1_EJBME-17-011

Full Length Research Paper

\title{
ICT and growth gap between nations: Evidence from MENA region
}

\author{
Najeh AISSAOUI \\ CODECI (Research Unit) Faculty of Economics and Management of Sfax; \\ PO Box 115, the great Maghreb 3049 Sfax; Phone: 00216 97189457; Email: aissaoui.najeh@gmail.com.
}

Accepted 15 March 2017

The purpose of this paper is to examine the role played by ICT in explaining the dynamics of inequality between the MENA countries and OECD during the 2000s. To do this, we formalize an original model of cumulative growth with four simultaneous equations. As a result, we note three interesting findings. Firstly, ICT investment had an important role in increasing the revenue inequality between the MENA region and OCDE. Secondly, the cumulative and mutual causality relationship between ICT investment and growth rate is apparent. Thirdly, the interaction between human capital and ICT investment can be considered as an important canal which allows the inequality reduction for the MENA countries.

Keywords: ICT Investment, Economic Growth, Growth Gap, Human Capital.

JEL classification: O11, O31, O47, E22.

\section{INTRODUCTION}

Since the eighties, the global economy has undergone profound changes characterized by the spread of new information and communication technologies (Dilek, 2016). This information revolution can be ranked among the most important seismic movements in the economic history at the same level as the industrial revolution and the invention of electricity. Indeed, it has reduced the cost of goods. These downward pressures on prices exerted by the application of new technologies led to an increased competition and an accelerated economic growth. This combination helps to maintain a healthy economy, without excess. Such an environment promotes productivity growth and business performance and stimulates market activity, pushing some sectors, starting with the technology to new heights.

However, the information revolution was accompanied by rising inequality between nations in terms of economic growth. The dispersion on the rise in average incomes has favored some countries compared to others that remain behind. This concerns both the developed and the developing countries. It is, of course, a universal and inevitable phenomenon. Knowing the potential causes of this phenomenon is one of the main interests of academic economists and political leaders.

The analysis of the growth gap between the United States and the other developed countries has raised many controversies regarding the factors responsible for the widening of this gap in the 90s (Aghion and Howitt, 2006, Gust and Marquez, 2004 Nicoltti and Scarpetta, 2003). Most recent studies have attributed this dynamic growth gap to the information and communication technology (Kahouli, 2012; Schreyer, 2000; Dewan and Kramer, 2000; Pohjola, 2000; Daveri, 2002; Colecchia and Schreyer, 2002; Jalava and Pohjola, 2002, Oliner and Sichel, 2003). Indeed, the uneven diffusion of ICT among regions and countries creates a digital divide widening the growth gap between countries which are able to benefit from the opportunities provided by new technology and those which are not (Aissaoui and Hassen, 2016). In this sense, Seo, Lee and Oh (2009) have argued that countries that have taken full advantage of these opportunities in 1990 (such as America, Finland and Ireland) have shown 
superior results in terms of economic growth compared to others, for example Japan.

The existing international works comparing the economic effects of ICT among nations suffer from three major constraints. Firstly, most studies focused on convergence (their main object is to analyze the convergence of economies and not to seek the effects of ICT on inequality). Secondly, studies devoted to the developing countries are still very limited (especially in the MENA region) and often show non-significant effects (Pohjola, 2000; Lee, Gholami and Tong (2005), among others). Thirdly, these works aim only at a unilateral relationship (in an only one direction: if ICT affects economic growth). The study of Seo, Lee and Oh (2009) attempted to address this limit trying to look for an inverse relationship for a group of developed and developing countries, but it failed to show a significant effect in both directions.

We formalize an original model of cumulative growth with simultaneous equations in order to study the role played by ICT in explaining the dynamics of the growth gap between Nations.

Our study extends essentially that of Seo, Lee and Oh (2009) if we consider the following two dimensions: First, we are working on a group of countries in the MENA region (11 countries) ${ }^{1}$ for a longer and more recent period, with reference to a panel data analysis. Second, we introduce a new equation with a new variable that reflects the interaction between human capital and ICT investment. This will help us better explain the dynamics of inequality and find an indirect effect by which ICT can reduce the gap separating the countries of MENA region and those of the OECD.

This paper has two objectives. First, it aims at analyzing the relationship of interdependence between economic growth and ICT investment and understanding their theoretical stakes.=Second, it tries to examine the role played by ICT in explaining the dynamics of income inequality between the MENA countries and OECD group. To do this, in the first two sections, we present some background devoted to the analysis of the impact of ICT investment on economic growth, as well as the ICT-growth inequality relationship between Nations. In the last section, we empirically apply these relations for the MENA region using our model of cumulative growth.

\section{ICT and economic growth}

There are two different approaches which study the impact of technological change on the output and productivity growth (Martinez, Rodriguez and Torres, 2009). The first, which is the more used than the second, is the traditional growth accounting (Jorgenson and Stiroh, 2000; Oliner and Sichel, 2000; Daveri, 2002; Colecchia and Schreyer, 2002; Jalava and Pohjola, 2002; Timmer, Ypma \& Van Ark, in 2003, among others). The second approach uses dynamic general equilibrium models to quantify the contribution of the technological change to growth (Greenwood et al., 1997, 2000; Kiley, 2001; Pakko, 2005, Martinez, Rodriguez and Torres, 2009, among others). Thanks to these two approaches, a multitude of empirical studies have tried to detect the role of ICT in the acceleration of the potential growth in countries.

\section{Limited effect often invisible}

In 1987, Robert Solow argued that: "You can see the computer age everywhere these days, except in the productivity statistics " (New York Times Book Review, July 12th, 1987). Several macroeconomic studies have shown a non-existent or even negative effect of information and communication technology on economic growth (Brynjolfsson and Yang, 1996). Motohashi (1997) found a weak correlation between productivity and intensity in IT for five OECD countries. Gordon (2000) has also been very pessimistic regarding the impact of ICT on productivity. Indeed, he attributed, on the one hand, a sizeable portion of growth in labor productivity observed in the late 1990s to cyclical factors and, on the other hand, he found that in $88 \%$ of the economy, the impact of new technology on productivity is absent and the ICT capital is unproductive.

Thus, despite the general view that sustains that ICT has brought about a new technological revolution, some economists see that the measured impact of ICT on aggregate productivity has been very limited so far and that the effects of these forces take time to become visible on the macro- economic level. Jalava and Pohjola (2002) have indicated that the impact of electronic commerce and the Internet on productivity and economic growth is difficult to detect. Several studies, such as those of Kiley (2001), have mentioned that before the new equipment is completely adapted, the implementation of ICT is a technological revolution having a substantial short-term negative effect. The transitional dynamics of change in technological progress has led to a slowdown in capital accumulation, and therefore a slowdown in productivity during the transition period. By integrating into this tradition of research, Pakko (2002) uses a stochastic growth model to show that a change in the growth rate of the technological progression may affect productivity not simultaneously, but with a delay. Hornstein and Krusell (1996) argue that an increase of technological change may cause a temporary slowdown in productivity, given the average knowledge's decrease, because there are relatively more resources allocated to new capital.

Several studies, such as that of Attwell 1991 and Brynjolfson 1993, have offered variety of explanations of the non-visibility causes of productivity gains from 
Information Technologies. These explanations can be summarized into four different groups:

Measurement errors: Some gains from ICT, such as, improving the quality and variety of products or the appearance of new services, are not taken into account by productivity measures. Besides, the rapid decline in prices makes it difficult to measure the IT stock. Applegate, Cash and Mills (1988) argue that a part of the IT value is to make the businesses more flexible and create new tasks, instead of just increasing productivity.

Time lag for diffusion: David (1989) argues that most of the productivity gains coming from the application of the electric-dynamo became visible only 40 years after the introduction of this technology. Indeed, prior to the realized potential benefits, the new technology needs time to be disseminated and organizationally adopted. Therefore, there is a considerable gap between the time of investment and the time to achieve the productivity gains (after the fact that organizations introduce ICT, learn to use them, and adopt their needs).

Redistribution: Information Technology can be of benefit to individual firms by providing them with a competitive advantage, but not to the economy as a whole. Therefore, it just redistributes the output without increasing it.

IT Management: To achieve potential benefits, the new technology requires an organizational change. The study of David (1989) has shown that this is not the only diffusion that achieves productivity gains of electricdynamo, it is rather the combination of widespread diffusion with a radical change in the production process which results in a productivity boom.

Probably, there is a lag between the time of investment in information technology and the time to achieve productivity gains. Newer studies have tried to overcome the problem of measurement errors and time lag for diffusion by using large samples for long periods. Such researches could show a significant positive effect of ICT investment on economic growth.

\section{Visible positive effect}

Using econometric evidence at the sector level and for the period 1990-2008, Khuong (2014) showed a strong correlation between IT adoption and Singapore's growth and argued that the contribution of ICT to growth increased sharply during three sub period. In the same context, a study by Pohjola (2000) revealed that IT investment has a strong influence on economic growth in the developed countries but not in the developing ones. Using a standard neoclassical model of accounting growth, Oliner and Sichel (2000), found that the use of information technology positively contributes to production and productivity. These effects were observed especially in the 2 nd half of the 1990s. Likewise, the production of computers significantly contributes to economic growth.

Jalava and Pohjola (2002) consider that ICT are both an output for producing ICT industries and an input for industries using ICT. They used a model of accounting growth to assess the ICT contribution to economic growth. This model helped them detect three fundamental ways in which ICT can stimulate economic growth. First, the production of ICT goods and services directly contributes to the added total value of an economy. In fact, rapid technological progress increases the productivity of ICT-producing industries. Second, the use of ICT capital, as a factor of production of other goods and services, can have a significant effect on economic growth. Maximizing their profits, firms respond to lower prices of ICT by the substitution of capital equipment and structures by ICT equipment and software. The resulting increase in capital intensity will raise the labor productivity of ICT-using industries. Oliner and Sichel (2000) showed that half of the labor productivity in the United States has been due to an increase in the use of ICT capital in production. Third, ICT can stimulate economic growth through the impact of ICT-producing industries on the multi-factorial productivity. Jalava and Pohjola (2002) state that production and the use of ICT are the factors behind the improvement of the economic performance of the United States during the 90 s and that the production of ICT has not been a necessary condition to undergo the effects of ICT on growth. Indeed, in Australia, the contribution of ICT to the output increased during the 1990s by about $0.6 \%$, although this country was not a significant producer of ICT during this same period. Colecchia and Schreyer (2002) reinforced this idea and showed that ICT investment rate has been increasing in all the studied countries (Australia, Canada, Finland, France, Germany, Italy, Japan, United Kingdom, United States) and that the relative and absolute decline in prices engendered by the increase in the demand for IT investment entailed a substitution effect to the profile of IT goods. In addition, the United States has not been the only country that benefited from the positive effects of ICT investment on the economic growth, where the effects have been clearer, but also did Australia, Finland and Canada. Similarly, Lee, Gholami and Tong (2005), using Solow residual and time series, found that, recently, investment in ICT has positively contributed to the improvement of national productivity in many developed countries and industrialized economies (EIN), but not in the developing countries. More recently, Kahouli (2012) showed a positive correlation between ICT and growth for both developed and developing countries but the impact is stronger for the first than the second. 
The fact that numerous studies found a positive impact of ICT on economic growth in the developed countries and an insignificant or weak effect in the developing countries, a finding emerged: ICT are a new source widening the growth gap between the developed countries, which enjoyed the benefits generated by this technology during the $90 \mathrm{~s}$, and the developing countries.

\section{ICT and growth gap between nations}

Although Information Technologies have been considered as a source of economic growth in the long term, there is still concern about its contribution to the worsening of the growth gap between nations (Kiiski and Pohjola, 2002). In this sense, the International Monetary Fund (IMF) emphasized that delayed countries should well reap the benefits of the new technologies since it can have adverse impacts ${ }^{2}$. In the same order of ideas, using a model of cumulative growth and attribute rising gap in growth among countries to ICT, Seo, Lee and Oh (2009) analyzed the effect of the interaction between ICT investment and economic growth regarding the gap between nations. These authors emphasized that the unequal access to IT by countries and regions gives birth to a digital divide which may explain this increase.

The Existing theories about international income difference focus on technology transfer (Basu and Weil, 1998; Parente and Prescott, 1999; Acemoglu and Zilibotti, 2001; Acemoglu, Aghion and Zilibotti, 2002). In this context, Howitt and Foulkes (2002) put forward three arguments by which the technological change may explain the widening growth gap between countries. The first argument focuses on the technological investment. Indeed, since technological transfer has been a difficult process, it is not possible for the recipient countries to receive foreign technology and implement it without cost. These countries have to invest in this matter in order to control and adopt foreign technology, which is often tacit and circumstantial, to their local environment. In short, any act of technology transfer requires innovation on the part of the recipient country. This innovation requires investment in $R$ \& $D$ and in a broader sense, technological investments. The second argument assumes that the innovation activity in a country requires a stock of "effective skills" which depends on its level of development regarding the world technology frontier from which it receives new ideas. This stock of skills is divided into two parts. The first part is the externality of human capital: in a technologically backward country, trainings (anything at school or otherwise) will produce low skills due to the lack of modern equipment. The second is the effect of the increasing complexity and the "fishing out". As the global technological frontier is moving forward and becoming increasingly complex, the lagging countries are forced to raise their level of knowledge in order to maintain the same speed with those across the border. The combination of the effect of the human capital externality and "fishing out" causes for a country which does not follow the pace of the border, a catching up increasingly difficult and an absorption capacity degrading. The third argument behind the divergence between nations is the appearance of a new set of scientific ideas and attitudes associated with the scientific revolution. The increase of modern economic growth following the first industrial revolution has closely been associated with these ideas and attitudes which created a new era of technological change. This movement, which emerged in the 19th century, was accompanied by the introduction of $R \& D$ laboratories exploiting the interconnection between science and technology and the emergence of many institutions, such as government research laboratories, universities related to industry and commerce ...). In the same context, some studies supported the idea that ICT can have negative effects on the convergence of the developing countries (Guetat and Drine (2007)). Indeed, it facilitates the attraction and opening of new markets in the developed countries (countries through their comparative advantages) at the expense of the nondeveloped countries. The latter ones will not only be less competitive on the international market, but also be threatened in their local markets. Therefore, this process can widen the gap between the developed and the developing countries.

\section{ICT, growth and gap growth: The case of MENA region}

The efforts made by the countries of the MENA area, especially those of the Arab Spring before the revolution concerning trade openness, international cooperation and attractiveness of foreign direct investment matters, surprised economists who thought that these achievements have placed the Arab countries in a direction of convergence with their European partners. In fact, the MENA region achieved a growth rate of over $4 \%{ }^{3}$ per year during the 2000-2009 period, alongside significant progress in productivity related to the knowledge economy (especially in Tunisia, Egypt, Morocco and Jordan). However, this did not prevent the persistence of a high poverty, an increasing inequality (chiefly related to the large commercial disequilibrium with Europe and the inadequacy of the supply of skills) and a very high rate of youth unemployment (graduates).

These effects led to some recent studies with the purpose of detecting the determinants of economic growth in the MENA region (eg, Sassi and Goaied, 2013; Guetat 2006; Ouled Aoudia, 2006). Similarly, the notion of convergence in the MENA region has recently been studied but the involved empirical studies are still been limited (Guetat and Serranito 2008; Erlat 2007; Duasa, 2008 Sarranito, 2009). These studies indicate that, apart 


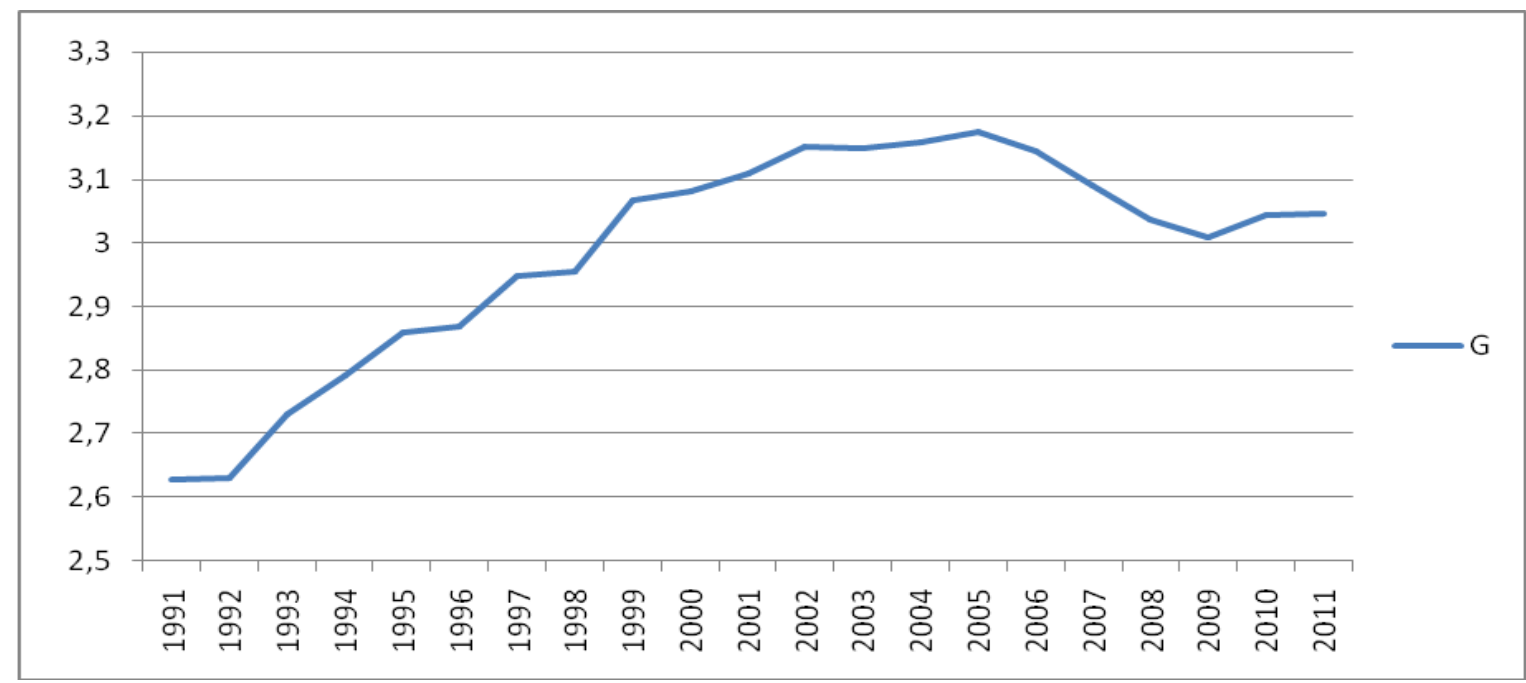

Figure 1. growth gap between the oecd and the mena countries ${ }^{5}$ (Source: World development indicators online)

from the 1973-1984 period, the income of the countries in the MENA region do not converge to the south of Europe. Sarranito (2009) modeled a logistic function of diffusion of technical progress at the international level and showed that we can have a catch-up process if the diffusion coefficient is quite high. He applied this model to eight countries in the MENA region to study their catch up to the European level and showed that Tunisia and Egypt entered a process of convergence (a low speed between 0.8 and $1 \%$ ) as soon as the 1970 s, while Algeria, Jordan and Syria are in a divergent phase. Turkey, which is a member of the European Union, has experienced a significant divergence since 1993.

\section{The trend of growth gap since the $90 \mathrm{~s}$}

The literature mentioned above, as well as the empirical studies on inequality, have often and for a long time (until the end of the twentieth century) shown a widening or aggravation of the income inequality between the developed and the developing countries. Figure 1 presents an overview of income inequality, for twenty years, between the OECD group of countries and the MENA region.

A continuous increase in inequality had been observed until 2005, and then, for the first time, a slight reduction in this gap was noticed. This is one of the reasons behind our choice to study this period (2000-2009) ${ }^{4}$.

\section{Empirical model}

In order to evaluate the impact of ICT on growth and on the dynamics of income inequality between countries in the MENA region and the OECD, we are considering a Cobb-Douglas function under the following form:

$Y(t)=A(t) L^{\alpha}(t) H^{t i c}{ }^{\beta}(t) \operatorname{tic}^{\theta}(t)$

Where $\mathrm{Y}$ the GDP, $\mathrm{L}$ the labor, $\mathrm{A}$ the level of technology, Htic the non-ICT capital and ICT the ICT capital. The decomposition of the capital into two (depending on whether the capital is ICT or not) has often been adopted in the literary background on the topic (Jorgenson and Stiroh, 2000; Gilles and L'Horty, 2003; Ben Youssef and $M$ ' Henni, 2004). We assume that the economy includes two countries: the leader country (or country of the technological frontier, indicated by I), which has fully benefited from the positive effects of technology, and the recipient country, which is the follower (indicated by s).

In terms of productivity, expression (1) becomes:

$Y_{\mathrm{S} / \mathrm{L}_{\mathrm{s}}}=\mathrm{PRO}_{\mathrm{s}}=\mathrm{A}_{\mathrm{s}} \mathrm{L}_{\mathrm{s}}^{\alpha-1} \mathrm{Htic}_{\mathrm{s}}^{\beta} \mathrm{TiC}_{\mathrm{s}}{ }^{\theta}$

If one examines the growth rate, he will get:

pro $_{s}=a_{s}+(\alpha-1) \bar{l}_{s}+\beta$ htic $_{s}+\theta$ tic $_{s}$

With pro, I, htic and tic are the growth rates of productivity, labor, non-ICT capital and ICT capital respectively.

For reasons of simplification, it is assumed that labor is growing at a constant annual rate (Like Dowrick and Nguyen (1989). 
According to Dowrick and Nguyen (1989) and Seo, Lee and Oh (2009), technological change depends both on domestic innovation (noted by Id) and foreign technological externalities (noted by $\mathrm{C}$ ). We will therefore:

$A_{s}=I_{d}^{\delta} C_{s}{ }^{n}$

In terms of growth rates, this can be written as:

$\mathrm{a}_{\mathrm{s}}=\delta \mathrm{id}_{\mathrm{s}}+\eta \mathrm{c}_{\mathrm{s}}$

The protection of intellectual property rights constitutes one of the principal means that encourages innovation. Moreover, human capital is a key factor for this activity. Whence:

$\mathrm{id}_{\mathrm{s}}=\delta_{0}+\delta_{1} \mathrm{sec}_{\mathrm{s}}+\delta_{2}$ tert $_{\mathrm{s}}+\delta_{3} \mathrm{dpi}_{\mathrm{s}}$

With sec, tert and dpi are, respectively, the secondary school enrollment rate, the tertiary school enrollment rate and the degree of protection of intellectual property rights.

According to the theories of economic catch-up, we will attribute the relative growth backwardness (Let the notes G) and the absorptive capacity of the country to foreign technological externalities. $\mathrm{G}_{\mathrm{s}}$ defined as:

$\mathrm{G}_{\mathrm{s}}=\log \left(\mathrm{y}_{/} / \mathrm{y}_{\mathrm{s}}\right)$

With $y_{s}$ and $y_{1}$ denoting the productivities of the recipient and the leader country, respectively.

Therefore, we have:

$\mathrm{c}_{\mathrm{s}}=\mathrm{c}_{0}+\Omega \mathrm{G}_{\mathrm{s}}$

Equations (3), (5), (6) and (8) give us :

$\operatorname{pro}_{\mathrm{s}}=\delta\left[\delta_{0}+\delta_{1} \sec _{\mathrm{s}}+\delta_{2}\right.$ tert $\left._{\mathrm{s}}+\delta_{3} \mathrm{dpi}_{\mathrm{s}}\right]+\eta\left[\mathrm{c}_{0}+\Omega \mathrm{G}_{\mathrm{s}}\right]+$ $(\alpha-1) \bar{l}_{\mathrm{s}}+\beta$ htic $_{\mathrm{s}}+\theta$ tic $_{\mathrm{s}}$

pro $(\mathrm{t})=\left(\delta \delta_{0}+\eta \mathrm{c}_{0}\right)+\eta \Omega \mathrm{G}_{\mathrm{s}}+\delta \delta_{1} \mathrm{sec}_{\mathrm{s}}+\delta \delta_{2}$ tert $_{\mathrm{s}}+\delta \delta_{3}$

$\mathrm{dpi}_{\mathrm{s}}+(\alpha-1) \bar{l}_{\mathrm{s}}+\beta$ htic $_{\mathrm{s}}+\theta$ tic $_{\mathrm{s}}$

This one is our first equation of the simultaneous equation model.

According to the principle of acceleration (Amable, 1993 Boyer, 1988; Dixon and Thirlwall, 1975), non-ICT investment has been assumed to be influenced by the growth rate of demand. It is also a function of the real interest rates and government spendings.

From here emanates our second equation:

htic $_{\mathrm{s}}=\alpha_{0}+\alpha_{1} y_{s}+\alpha_{2} r_{s}+\alpha_{3} g_{0 v_{s}}+\varepsilon_{2}$

With $y$ the growth rate of demand, $r$ the real interest rate and gov the government spending.
As shown Caselli and Coleman (2001), the investment equation in ICT is as follows:

tic $c_{s}=\gamma_{0}+\gamma_{1} y_{s}+\gamma_{2} r_{s}+\gamma_{3} g_{0 v_{s}}+\gamma_{4}$ tert $_{s}+\gamma_{5}$ ouv $_{s}+\gamma_{6} h_{s}+\gamma_{7}$ $r d+\varepsilon_{3}$

With: ouv the degree of trade openness, ht the industrial structure and $r d$ the spending on R\&D.

Kiiski and Pohjola (2002), Baliamoune -Lutz (2003) and Caseli and Colemen (2001), on the basis of an empirical analysis, showed a positive correlation between ICT investment and human Resources (tert), which shows that the increase in human capital leads to a return on investment in ICT. Trade openness also plays an important role in the increase of investment in ICT. In fact, according to Grossman and Helpman (1991), BenDavid and Loewy (2000), and Baliamoune-Lutz (2003), trade openness facilitates the diffusion of new technology through the increase of intra-firm competition. Caselli and Coleman (2001) showed that industrial structure has a positive impact on investment in ICT. Similarly, the activity of the research and development can be an important factor for the investment in ICT.

Finally, our fourth equation is the following:

Gs $=\lambda 0+\lambda 1$ tics $+\lambda 2$ htics $+\lambda 3 \mathrm{Ns}+\varepsilon 4$

Where $\mathrm{N}$ is the interaction between ICT investment and human capital.

We have formulated this relationship in order to detect the direct and indirect effects (through an interaction with human capital) of ICT in the explanation of the dynamics of growth inequality.

Thus, our model to estimate is the following:

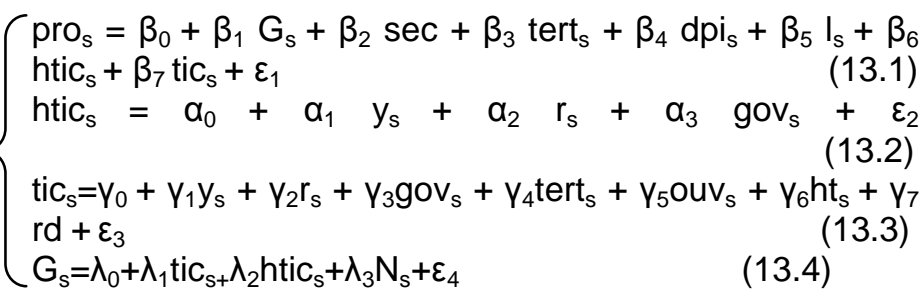

This is a model of four simultaneous equations, the first of which is a cumulative growth model. Its originality lies in the fact that it can detect the determinants of ICT and non-ICT investments, analyze the interdependent relationship between ICT investment and economic growth, and examine the role of ICT in explaining the dynamics of inequality between countries. The regression methods of such model are based on the identification of different equations. Indeed, the blind application of the ordinary Least Squares Method can lead to misleading results to the extent that the hypothesis of independence between the explanatory variable and the error is not respected. 
Table 1. Estimation of the simultaneous equation model

\begin{tabular}{|c|c|c|c|c|}
\hline \multicolumn{5}{|c|}{ Three-stage least-square regression } \\
\hline Equation & RMSE & «R-sq » & Chi2 & P-value \\
\hline pro & 1.742 & 0.123 & 24.64 & 0.001 \\
\hline htic & 3.257 & 0.687 & 49.31 & 0.000 \\
\hline tic & 0.913 & 0.854 & 145.53 & 0.000 \\
\hline$g$ & 0.648 & 0.873 & 144.6 & 0.000 \\
\hline & Coef. & Std. Err. & $\mathbf{Z}$ & $P>|z|$ \\
\hline pro & & & & \\
\hline g & 4.009 & 2.067 & 1.94 & 0.052 \\
\hline tert & -0.005 & 0.111 & -0.05 & 0.962 \\
\hline $\sec$ & 0.169 & 0.085 & 1.99 & 0.046 \\
\hline I & 0.311 & 0.247 & 1.26 & 0.208 \\
\hline dpi & 0.001 & 0.001 & 1.88 & 0.061 \\
\hline tic & 0.178 & 0.639 & 3.41 & 0.001 \\
\hline htic & 0.403 & 0.199 & 2.02 & 0.043 \\
\hline -const & -57.064 & 26.573 & -2.15 & 0.032 \\
\hline htic & & & & \\
\hline y & 0.326 & 0.312 & 1.05 & 0.295 \\
\hline$r$ & -0.181 & 0.157 & -1.16 & 0.246 \\
\hline gov & -0.632 & 0.138 & -4.58 & 0.000 \\
\hline -const & 27.531 & 3.212 & 8.57 & 0.000 \\
\hline tic & & & & \\
\hline$y$ & 0.343 & 0.098 & 3.48 & 0.000 \\
\hline$r$ & 0.003 & 0.072 & 0.04 & 0.968 \\
\hline gov & 0.361 & 0.146 & 2.46 & 0.014 \\
\hline tert & 0.124 & 0.047 & 2.61 & 0.009 \\
\hline ouv & -0.0527 & 0.055 & -0.96 & 0.338 \\
\hline ht & 0.102 & 0.074 & 1.37 & 0.170 \\
\hline dpi & 0.000 & 0.000 & -1.19 & 0.235 \\
\hline rd & -1.307 & 0.453 & -2.88 & 0.004 \\
\hline -const & -4.251 & 1.563 & -2.72 & 0.007 \\
\hline g & & & & \\
\hline tic & 0.641 & 0.244 & 2.62 & 0.009 \\
\hline htic & -1.101 & 0.058 & -1.75 & 0.081 \\
\hline $\mathrm{n}$ & -0.022 & 0.004 & -5.03 & 0.000 \\
\hline -cons & 6.243 & 1.290 & 4.84 & 0.000 \\
\hline
\end{tabular}

Endogenous variables: pro, htic, tic, g; Exogenous variables: tert, sec, l, dpi, y, r, gov, ouv, ht, rd, N

The indicators used to measure both the exogenous and endogenous variables are shown in Table 4 (see Appendix 1).

\section{ECONOMETRIC RESULTS AND INTERPRETATIONS}

Table 1 shows the output of our empirical estimation (regression) of the model presented above (simultaneous equation model for a sample of 11 countries in the MENA region cover the period 2000-2009).

Based on the regression technique of the three least squares (3SLS) (to control endogeneity problems), our empirical results suggest that:

In the first equation, the estimated coefficients of variables "g", "htic" and "tic" are positive, have expected signs, and are statistically significant. This confirms the results obtained by Gust and Marquez (2004), Aghion 
and Howitt (2006), Conway et al. (2006) and Seo, Lee and Oh (2009). However, Dewan and Kraemer (2000) and Gholami and Tong (2005) argued that ICT investment contributes positively and significantly to economic growth but only for the developed countries. Our output proves this for the MENA region. Contrary to the tertiary enrollment rate (tert), the secondary enrollment rate (sec) affects positively and significantly the rate of productivity growth. This is essentially due to the inadequacy of the supply of skills, which, in turn, explains the considerable increase in the unemployment rate of university graduates in the MENA region. According to Helpman (1993), in the case where the only channel for technology transfer is imitation, increased intellectual property rights may reduce the rate of innovation, in the North, and the welfare, in the South. However, as mentioned in the table above, the intellectual property rights in the MENA region have a significant positive effect (but it is weak because its coefficient is equals to $0.1 \%$ ). This suggests that the innovative activity exists but has not yet been developed enough in the Arab countries. The estimated coefficient of employment shows a non significant positive sign.

For the second equation, neither economic growth nor the real interest rates affects the non-ICT investment. On the contrary, public expenditure has a significant negative sign (expected sign). Indeed, public spending hampers investment in non-ICT capital. This confirms the results obtained by Seo, Lee and Oh (2009).

Unlike with these authors, our third equation proves the existence of a significant positive effect of demand on ICT capital which, in turn, has a significant positive impact on productivity growth (vicious circle). In other words, the ICT investment contributes to productivity growth that boosts economic growth. The latter induces an increase in non-ICT investment; and so on ... Thus, our model helped us detect the existence of a

relationship of cumulative causation in both directions between economic growth and investment in ICT. In addition, the variables "gov" and "tert" have significant positive impact on ICT investment. Thus, public spending stimulates ICT investment and qualification is an important factor for technology transfer. The absence of a significant impact of intellectual property right on ICT investment makes us believe that the innovation activity is not strong enough to increase the ICT capital. In addition, it should be noted that expenditure in the R\&D (significant negative effect) hinders investment in ICT.

This third equation showed no significance for the real interest rate, trade openness as well as for industrial structure. The European Union is the principal trading partner of the MENA region. According to FEMISE (2011), Euromed agreements have resulted in large trade disequilibrium with Europe. This effect may offset the benefits coming from the trade openness, and subsequently explains the non-significance of the variable "ouv" on ICT investment in the MENA region.
According to See, Lee and Oh (2009), the significant positive impacts of ICT capital and non-ICT capital on productivity growth in equation 1 serve to emphasize the importance of these two variants in explaining the growth gap between nations. However, this gap depends on both the change in productivity of the follower and the leader countries. For this reason, we have formalized our fourth equation in order to explain the results obtained by Seo, Lee and Oh (2009) in a clearer and more comprehensive manner. Indeed, we observe a positive and significant effect of the variable "tic" by $5 \%$ on the growth gap between nations. This means that investment in ICT has been widening the gap during the 2000s in the MENA region. However, an interaction between the two variables "tic" and "tert" (expressed by the variable " $\mathrm{N}$ ") shows a highly significant and negative effect (by $1 \%$ ). Therefore, the variable $\mathrm{N}$ enables us to slightly reduce (the coefficient allocated is equal to $1.7 \%$ ) the variable G.

Finally, let us now return to our variable $\mathrm{V}$ (see Appendix $2)$, which is equal to $\frac{\eta_{1} \Omega}{\left(1-\beta_{x 1}-\theta_{r} 1\right)}$. We find $V=23.64>0$ so, there is a convergence (case 1 or 2 , it depends on the sign of $U$ ).

\section{Conclusion}

The objective of this paper is to analyze the role played by ICT in explaining the dynamics of income inequality between nations. To do this, using the method of three least squares (3SLS), we have tested a cumulative growth model with simultaneous equations for eleven countries of the MENA region during the period (20002009). Our results revealed some findings that should be kept in mind.

First, investment in ICT has played a key role in increasing the income inequality between the MENA and OECD area during the 2000s. However, the causal cumulative relationship between ICT investment and the rate of productivity growth, in both directions, is apparent: ICT investment helps increase productivity and subsequently economic growth, which, in turn, accelerates investment in ICT. Although this relationship is visible, we can see that the countries of the MENA region have not yet reached the stage where they rely on ICT to reduce the growth gap.

However, an interaction between human capital and ICT shows a negative and significant effect on this gap. This shows that ICT investment is a necessary but not sufficient condition (for MENA) to enjoy the benefits generated by the digital economy and eventually catch up on the developed countries. This interaction can be manifested in various forms: an integration of ICT in higher education, a concentration on ICT training in order to improve the digital skills of employees in companies, 
development of technological branches in the education system, the creation of research laboratories that can provide the interconnection between science and technology.

Then, the non-ICT investment contributes also to increased productivity in the MENA region and reduces the growth gap. Therefore, the incentive to invest in ICT must not be at the expense of other types of investment.

Furthermore, a strengthening of the intellectual property rights in the MENA region, through the stimulation of innovation activity, can be an important channel through which this region can reduce the growth gap which separates it from the OECD countries.

Note, finally, that the Euromed agreements with our European partner must be revised in order to fully benefit from the positive effects of trade openness on technological diffusion and economic growth.

\section{ENDNOTES}

1. Algeria, Egypt, Iran, Israel, Jordan, Kuwait, Morocco, Saudi Arabia, Tunisia, UAE and Turkey.

2. Fourth chapter of World Economic Outlook "Globalization and inequality »

3. Report FEMISE the Euro-Mediterranean Partnership (2011).

4. The Other causes are the timeliness and availability of data especially on ICT investment in the MENA region during this period.

5. The Gap growth is calculated here as the ratio between the group productivity OECD countries and the productivity of the group of the countries of MENA region.

\section{REFERENCES}

Acemoglu D, Zilibotti F (2001). Productivity Differences. Quart. J. Econ. (116): 563-606.

Acemoglu D, Aghion P, Zilibotti F (2002). Distance to Frontier, Selection and Economic Growth. J. Eur. Econ. Assoc. 4(2): 37-74.

Aghion $P$, Howitt $P$ (2006). Appropriate growth policy: A unifying framework. J. Eur. Assoc. 4: 269-314.

Aissaoui N, Ben HL (2016). Diffusion Technologique et Inégalités Numériques : Une Exploration de la Fracture Numérique dans la Région MENA. Statéco, (110): 105-121.

Amable B (1993). Catch-up and Convergence: A model of Cumulative Growth. Intl. Rev. Appl. Econ. 7: 1-25.

Applegate LM, Cash JI, Mills DQ (1988). Information Technology and Tomorrow's Manager. Harvard Bus. Rev. 88(6): 128-136.

Attewell P (1993). Information Technology and the Productivity Paradox. CUNY, Mimeo.

Baliamoune-Lutz M (2003). An Analysis of the Determinants and Effects of ICT Diffusion in Developing Countries. In. Technol. Develop. 10(3): 151-169.

Basu S, Weil DN (1998). Appropriate Technology and Growth. Quart. J. Econ. (113): 1025-1054.

Ben DD, Loewy MB (2000). Knowledge Dissemination, Capital Accumulation, Trade, and Endogenous Growth. Oxford Econ. Papers. (52): 637-650.
Ben YA, M'Henni H (2004). Les effets des Technologies de L'information et de la Communication sur la Croissance Economique: Le cas de la Tunisie. Revue Région et Développement, (19).

Boyer R (1988). Formalizing Growth Regimes. Technical Change and Economic Theory. Pinter.

Brynjolfsson E, Yang S (1996). Information Technology and Productivity: A review of the Literature. Quart. J. Econ. (43): 179-214.

Brynjolfsson E (1993). The Productivity Paradox of Information Technology. Communications of the ACM, 36(12): 66-77.

Caselli F, Coleman WJ (2001). Cross-Country Technology Diffusion: The Case of Computers. American Econ. Rev. (91): 328-335.

Colecchia A, Schreyer P (2002). ICT Investment and economic growth in the 1990s: Is the United States A Unique Case?. Rev. Econ. Dyn. (5): 408-442.

Conway P, De Rosa D, Nicoletti G, Steiner F (2006). Regulation, competition and productivity convergence. OECD Economics Department Working Papers, (509).

Daveri $F$ (2002). The new economy in Europe, 1992-2001. Oxford Rev. Econ. Pol. (18): 345-362.

David P (1989). Computer and Dynamo: The Modern Productivity Paradox in an not-too-distant mirror. The Warwick Economics Research Paper Series, University of Warwick.

Dewan S, Kraemer K (2000). Information technology and productivity: Preliminary evidence from country level data. Manage. Sci. (46): 548562.

Dilek S (2016). Enformasyon ve Bilgiye Dayalı Yeni Ekonomi. Kastamonu Üniversitesi IİBF Dergisi, (11): 87-91.

Dixon R, Thirlwall AP (1975). A Model of Regional Growth-Rate Differences on Kaldorian lines. Oxford Econ. Papers. (27): 201-214.

Dowrick S, Nguyen D (1989). OECD Comparative Economic Growth 1950-1985 : Catch up and Convergence. American Econ. Rev. (79): $1010-1030$

Duasa J (2008). Income convergence or divergence? Study on selected Muslim countries. MRPA Paper, (11563).

Erlat $\mathrm{H}$ (2007). Time series approaches to testing income convergence in MENA countries. In Topics in Middle Eastern and North African Economies, Proceedings of the Middle east Economic Association, (9), 355-378

FEMISE (2011). Les pays Méditerranéens au seuil d'une Transition Fondamentale. Rapport du FEMISE sur le partenariat Euroméditerranéen, Octobre.

Gilles F, L'Horty Y (2003). La Nouvelle Economie et le paradoxe de la productivité : une Comparaison France-Etats-Unis. http://t2m.univparis1.fr/eng/activities/colloques/ 2001/PDF/GILLES.FLHORTY.Y.pdf.

Gordon RJ (2000). Does the New Economy Measure Up to the Great Invention of the Past?. J. Econ. Perspect. 14(4): 49-74.

Greenwood J, Hercowitz Z, Krusell P (1997). Long-run Implication of Investment-Specific Technological Change. American Econ. Rev. 87(3): 342-362.

Greenwood J, Hercowitz Z, Krusell P (2000). The role of investmentspecific technological change in the business cycle. Eur. Econ. Rev. (44): 91-115.

Grossman GM, Helpman E (1991). Innovation and Growth in the Global economy. Cambridge, MA: MIT Press.

Guetat I, Drine I (2007). The Information and Communication Technologies Impact on MENA Countries Growth Performance. MEEA $6^{\text {th }}$ International Conference, Zayed University, UAE.

Guetat I, Serranito $F$ (2008). Convergence des pays de la région MENA vers le niveau de revenu des pays du sud de l'Europe : un examen empirique. Document de recherche du CEPN, (17), Université de Paris 13, France.

Guetat I (2006). The effects of corruption on growth performances of MENA countries. J. Econ, Financ. 30(2): 208-221.

Gust C, Marquez J (2004). International comparisons of productivity growth: The role of information technology and regulatory practices. Labor Econ. (11): 33-58.

Helpman E (1993). Innovation, Imitation, and Intellectual property rights. Econometrica, (61): 1247-1280. 
Hornstein A, Krusell P (1996). Can Technology Improvements Cause Productivity Slowdowns?. NBER Macroecon. Annual, 11: 209-276.

Howitt P, Mayer-Foulkes D (2002). R\&D, Implementation and Stagnation: A Schumpeterian Theory of Convergence Clubs. NBER Working Paper Series, (9104), August.

Jalava J, Pohjola M (2002). Economic growth in the new economy: Evidence from advanced economies. Inf. Econ. Pol. (14): 189-210.

Jorgenson D, Stiroh K (1999). Information Technology and Growth. American Econ. Rev. 89(2): 109-115.

Kahouli Z (2012). ICTs and Economic Growth : An Empirical Analysis with Panel Data. ARPN J. Sci. Technol. 2(5): 437-443

Kiiski C, Pohjola M (2002). Cross Country Diffusion of the Internet. Inf. Econ. Pol. (14): 297-310.

Kiley M (2001). Computers and growth with frictions: aggregate and disaggregate evidence. Carnegie-Rochester Conference Series on Public Policy, 55(1): 171-215, December.

Lee S, Gholami R, Tong T (2005). Time series analysis in the assessment of ICT impact at the aggregate level: Lessons and implications for the new economy. Inf. Manage. (42): 1009-1022.

Martinez D, Rodriguez J, Torres L (2010). ICT-specific technological change and productivity growth in the US: 1980-2004. Inf. Econ. Pol. (22): 121-129.

Motohashi K (1997). ICT Diffusion and its Economic Impact in OECD Countries. STI Rev. (20): 13-45.

Nicoletti G, Scarpetta S (2003). Regulation, productivity and growth: OECD evidence. Econ. Pol (18): 9-72.

Oliner S, Sichel D (2003). Information technology and productivity: Where are we now and where are going. J. Pol. Modeling. 25(5): 477-503.

Oliner S, Sichel D (2000). The resurgence of growth in the late of 1990s: Is information technology the story?. J. Econ. Perspect. (14) : 3-22.

Ould AJ (2006). Croissance et réformes dans les pays arabes méditerranéens. Rapport pour l'Agence Française du Développement (AFD), Paris, France.

Pakko MR (2005). Changing Technology Trends, Transition Dynamics, and Growth Accounting. Contributions to Macroeconomics 1, Article 12.

Parente SL, Prescott EC (1999). Monopoly Rights: A Barrier to Riches. American Econ. Rev. (89), 1216-1233.

Pohjola M (2000). Information technology and economic growth: A cross-country analysis. The United Nations University, WIDER, (173), January.

Schreyer P (2000). The Contribution of Information and Communication Technology to Output Growth: A Study of the G7 countries. STI Working Paper, OECD Publishing, (2).

Seo H, Lee Y, Oh J (2009). Does ICT investment widen the growth gap? Telecomm. Pol. (33): 422-431.

Serranito F (2009). Convergence et Rattrapage Technologique : Un test par les séries temporelles dans le cas des pays de la région MENA. http://www.academia.edu.
Timmer PM, Ypma G, Van AB (2003). IT in the European Union: Driving Productivity Divergence?. Research memorandum GD-67, University of Groningen.

Sassi S, Goaied M (2013). Financial Development, ICT Diffusion and Economic Growth: Lessons from MENA region. Telecomm. Pol. (37): 252-261.

Vu KM (2014). Information and Communication Technology (ICT) and Singapor's Economic Growth. Lee Kuan Yew School of Public Policy, National University of Singapore, n'LKYSPP14-08, May. 


\section{APPENDIX 1}

Table 2. Explanatory variables

\begin{tabular}{|c|c|c|}
\hline Variable & Indicator & Source \\
\hline Pro & The annual growth rate of GDP per worker & WDI (online) \\
\hline g & $\begin{array}{l}\text { Is the growth gap measured by the percentage of the country's productivity } \\
\text { compared to the OECD. }\end{array}$ & idem \\
\hline dpi & Patent applications, residents & idem \\
\hline 1 & Crowth rate of the active population & idem \\
\hline sec & The secondary enrollment ratio (gross) & idem \\
\hline tert & The rate of university enrollment (gross) & idem \\
\hline tic & ICT investment (\% of GDP) & $\begin{array}{l}\text { CD of the World Bank } 2008 \text { and } 2010 \\
\text { (WDI). }\end{array}$ \\
\hline htic & The non-ICT investment (\% of GDP) & idem \\
\hline y & The annual growth rate of GDP & WDI (online) \\
\hline $\mathrm{r}$ & Real interest rate & Idem \\
\hline gov & The government final consumption expenditures & Idem \\
\hline ouv & Measured by $: \sum$ (exports+imports)/GDP & Idem \\
\hline ht & The ratio of high-tech exports relative to manufactured exports. & Idem \\
\hline $\mathrm{rd}$ & Spendings on R\&D (\% of GDP) & \\
\hline $\mathrm{N}$ & $\begin{array}{c}\text { Is the interaction between human capital and investment in ICT calculated } \\
\text { by: tic tert }\end{array}$ & Idem \\
\hline
\end{tabular}

\section{APPENDIX 2}

If we return to equation (9) and we assume that $y_{s}=$ pros $_{s}+I_{s}$ (similar to Seo, Lee and Oh (2009)). Substituting equations (10) and (11) into equation (9), we obtain:

$\operatorname{pro}_{\mathrm{s}}\left(1-\beta \alpha_{1}-\theta \gamma_{1}\right)=\left(\delta \delta_{0}+\eta c_{0}+\beta \alpha_{0}+\theta \gamma_{0}\right)+\eta \Omega G_{s}+\delta \delta_{3} d p i_{s}+\delta \delta_{1} s e c_{s}+\left(\delta \delta_{2}+\theta \gamma_{4}\right)$ tert $t_{s}+\left(\alpha-1+\beta \alpha_{1}+\theta \gamma_{1}\right) I_{s}+\left(\beta \alpha_{2}+\theta \gamma_{2}\right) r_{s}+\theta \gamma_{5}$ ouv $_{\mathrm{s}}+\theta \mathrm{\gamma}_{6} \mathrm{ht}_{\mathrm{s}}+\left(\beta \mathrm{a}_{3}+\theta \mathrm{\gamma}_{3}\right) \mathrm{gov}_{\mathrm{s}}+\theta \mathrm{\gamma}_{7} \mathrm{rd}_{\mathrm{s}}$

So:

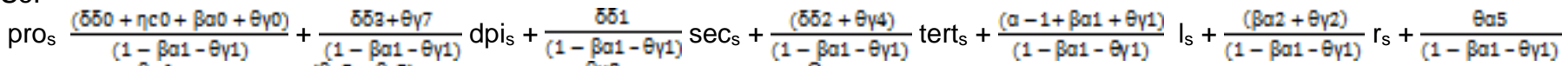

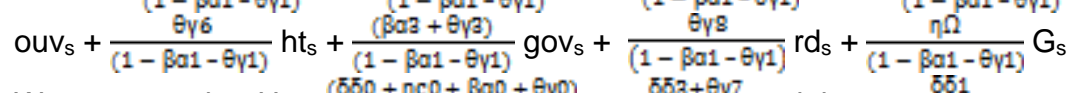

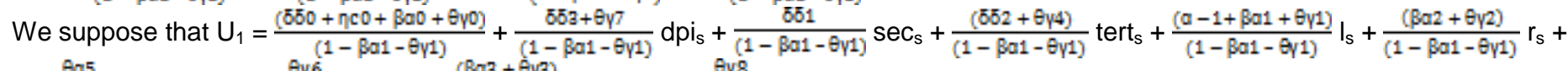

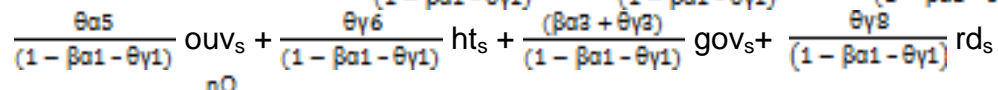

And $V=\frac{\eta \cap}{(1-\beta a 1-\mathbb{R} \gamma 1)}$

Then we have: $\operatorname{pro}_{\mathrm{s}}=\mathrm{U}_{1}+\mathrm{VG}_{\mathrm{s}}$

For the country of the frontier, $G=0$, as a result, productivity growth will be: $p_{1} \mathrm{I}_{\mathrm{I}}=\mathrm{U}_{2}$

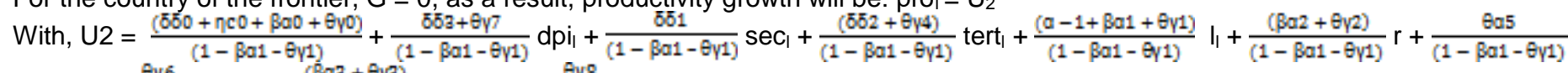

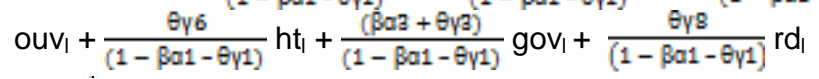

And $\dot{G}=$ prol $_{1}-$ pro $_{\mathrm{s}}=\mathrm{U}_{2}-\mathrm{U}_{1}-\mathrm{VG}_{\mathrm{s}}=\mathrm{U}-\mathrm{VG}_{\mathrm{s}}$

With $U=U_{2}-U_{1}=a_{1}\left(d p i_{1}-d p i_{s}\right)+a_{2}\left(s e c_{l}-s e c_{s}\right)+a_{3}\left(\right.$ tert $1-$ tert $\left._{s}\right)+a_{4}\left(l_{l}-l_{s}\right)+a_{5}\left(r_{l}-r_{s}\right)+a_{6}\left(o_{1} v_{l}-o u v_{s}\right)+a_{7}\left(h t_{l}-h_{s}\right)+a_{8}\left(g o v_{l}\right.$ $\left.-\operatorname{gov}_{\mathrm{s}}\right)+\mathrm{a}_{9}\left(\mathrm{rd}_{\mathrm{l}}-\mathrm{rd}_{\mathrm{s}}\right)$

As $\tilde{G}=U-\mathrm{VG}_{\mathrm{s}}$ donc

$\left\{\begin{array}{l}G_{s}=\frac{v}{V} \text { si } \dot{G}=0 \\ \dot{G}=V \text { si } G_{s}=0\end{array}\right.$

Four situations may arise, depending on the signs of $\mathrm{U}$ and $\mathrm{V}$ :

For the first case, there is a convergence but the follower country cannot fully catch up on the leader country because of the equilibrium $\mathrm{G}^{*}=\mathrm{U} / \mathrm{V}>0$. On the contrary, in the second case, the follower country catches up on the one which is technologically the leader and $G$ will be equal to zero. 


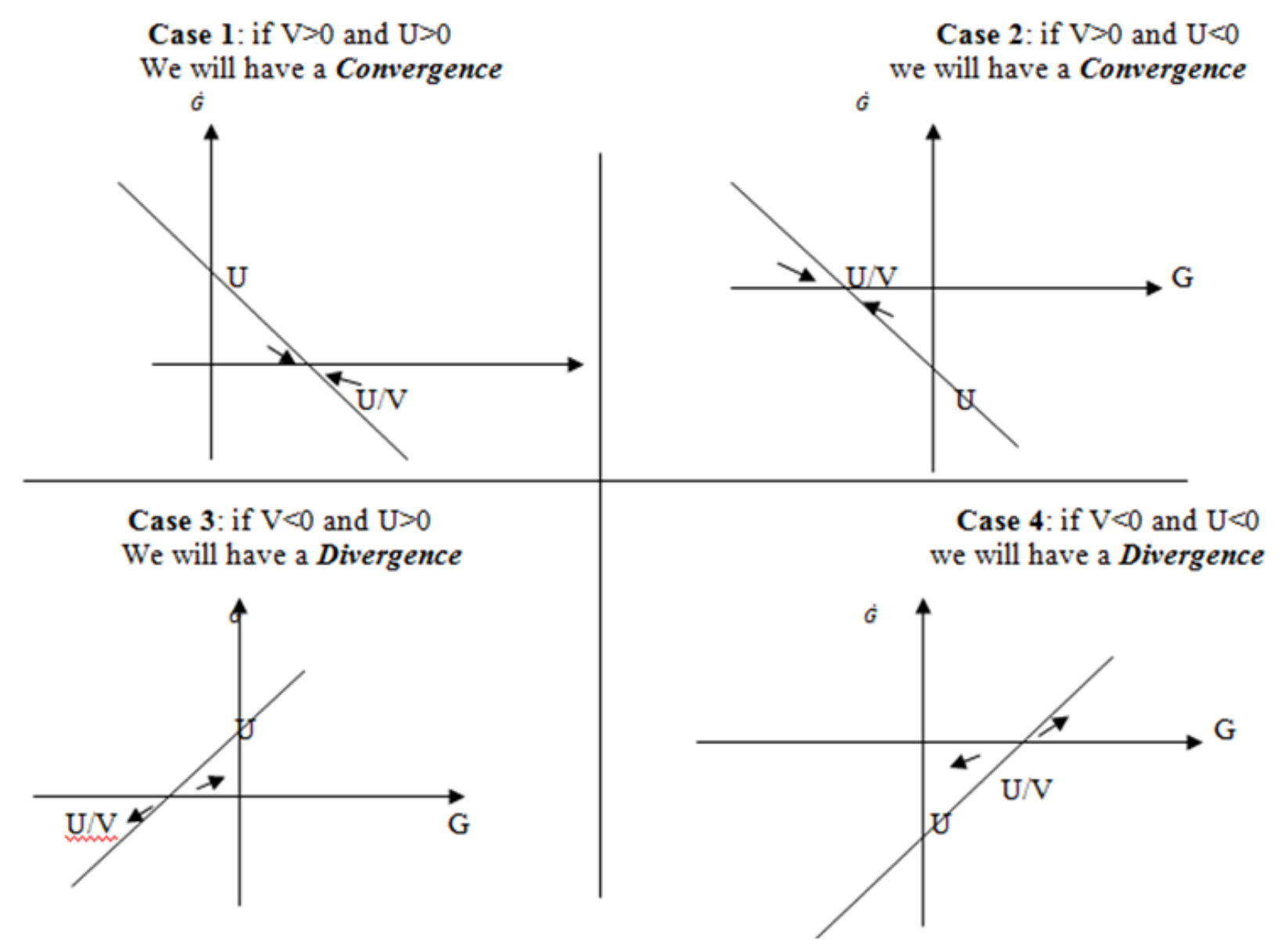

Figure 2. The dynamics of the growth gap between nations (Source: Seo et al., 2009) 